\title{
Perubahan Sosial Masyarakat Desa Akibat Penggunaan Sumber Air Bersama Perusahaan Daerah Air Mimum (PDAM)
}

\author{
Desi Yunita, ${ }^{1 *}$ Nunung Nurwati, ${ }^{2}$ Wahju Gunawan ${ }^{3}$ \\ 1,2,3 Departemen Sosiologi, Fakultas Ilmu Sosial dan Ilmu Politik, \\ Universitas Padjadjaran Bandung - Indonesia
}

\begin{abstract}
The water source in the Perhutani forest area is the main water source for the village community in Sumedang Regency West Java. At present, the same source is also used by the Sumedang Regency water company to meet the water needs of urban communities. This article describes the social changes that have occurred in rural communities as a result of the shared use of water resources from the Perhutani Forest. This article is based on qualitative research with a case study approach. Data collection techniques used were observation, interviews, and questionnaires. It was found that there have been social changes in forest-edge communities. The change is clearly seen in the changing pattern of planting and community agricultural commodities. Furthermore, it was found that changes also occurred in the mode of production (infrastructure) which was marked by the shift of control of the water source to the water company (PDAM), the changes in the mode of production directly affect changes in the structure of the forest village community which is mainly seen from changes in community livelihoods due to changes in agricultural patterns and systems in the community. Changes to the structure can also be seen from the formation of the existing water user structure at the RW level to regulate household water allocation and distribution.

Sumber air yang berada di kawasan hutan Perhutani merupakan sumber air utama bagi masyarakat desa yang tinggal di tepian hutan di wilayah kabupaten Sumedang Jawa Barat. Saat ini sumber yang sama juga dipergunakan oleh PDAM kabupaten Sumedang untuk memenuhi kebutuhan air bersih bagi masyarakat perkotaan. Artikel ini menguraikan perubahan sosial yang terjadi pada masyarakat desa tepian hutan sebagai akibat penggunaan bersama pada sumber mata air dari hutan Perhutani tersebut. Artikel ini didasarkan pada penelitian kualitatif dengan pendekatan studi kasus. Teknik pengumpulan data yang digunakan adalah observasi, wawancara dan kuesioner. Ditemukan bahwa telah terjadi perubahan sosial pada masyarakat tepian hutan Perhutani yang dipengaruhi adanya pemanfaatan sumber air yang sama oleh PDAM. Perubahan terlihat jelas pada berubahnya pola tanam dan komoditi pertanian masyarakat. Selanjutnya, ditemukan bahwa perubahan juga terjadi pada mode produksi (infrastruktur) yang ditandai dengan beralihnya kendali atas kontrol pada sumber air oleh PDAM, perubahan pada mode produksi ini secara langsung berpengaruh pada perubahan struktur masyarakat desa yang terutama terlihat dari berubahnya mata pencaharian masyarakat akibat berubahnya pola dan sistem pertanian di masyarakat desa tepian hutan. Perubahan pada struktur juga terlihat dari dibentuknya struktur pemanfaat air yang ada ditingkat RW untuk mengatur alokasi dan distribusi air rumah tangga.
\end{abstract}

Keywords: water source; social changes; infrastructure; structure

*Korespondensi Penulis: Desi Yunita (desi.yunita@unpad.acid), Departemen Sosiologi, Fakultas Ilmu Sosial dan Ilmu Politik, Universitas Padjadjaran Bandung, Jl. Bukit Dago Utara No.25, Dago, Kecamatan Coblong, Kota Bandung, Jawa Barat 40135. 


\section{Pendahuluan}

Indonesia tercatat sebagai negara dengan jumlah penduduk terbesar keempat di dunia yang wilayah perkotaannya terus bertumbuh. Perkiraan (World Bank 2018) 67,5\% populasi penduduk Indonesia akan hidup di daerah perkotaan pada tahun 2025. Pertumbuhan wilayah perkotaan ini turut mempengaruhi peningkatan kebutuhan akan air bersih, sehingga prediksi terjadinya kelangkaan air akan terus meningkat Faktor pendorong terjadinya kelangkaan air adalah meningkatnya populasi di wilayah perkotaan (Falkenmark dan Widstrand 1992; Turton dan Ohlsson 2018). Sehingga, muncul kekhawatiran adanya konflik akibat perebutan akses pemenuhan kebutuhan air bersih. Akibat adanya kekhawatiran itu, saat ini berkembang pemahaman tentang manfaat luas bagi ekonomi, pengguna, dan lingkungan jika air dikembangkan dan dikelola sebagai barang ekonomi, karena dengan meminta pengguna membayar seluruh biaya penggunaan air akan dapat mengatasi masalah-masalah tersebut (Briscoe, 2011). Selain itu, kelangkaan juga terjadi bukan saja karena air bersih yang berkurang, tetapi juga disebabkan oleh polusi yang meningkat akibat tekanan populasi (Liyanage dan Yamada 2017).

Peningkatan populasi yang menyebabkan polusi air tersebut ditandai dengan meningkatnya jumlah pemukiman (Glińska-Lewczuk et al. 2016), lahan pertanian untuk kebutuhan masyarakat luas (Stoyanova dan Harizanova 2019), dan industri komersil (Literathy 1996). Indikasi meningkatnya polusi air dikarenakan beberapa faktor tersebut juga teramati di wilayah Sumedang, tentu saja hal ini akan berpengaruh pada meningkatnya kebutuhan akan air untuk konsumsi (Wijitkosum 2012); (Morote-Seguido dan Hernández-Hernández 2016)). Dengan begitu maka dapat dilihat bahwa pertumbuhan populasi adalah penyebab utama kelangkaan air, karena pertumbuhan populasi telah mendorong meningkatnya permintaan dan persaingan dalam mendapatkan air untuk keperluan rumah tangga, industri, ataupun kota (Mogelgaard, 2011; McGrane, 2016).

Salah satu wilayah dengan pertumbuhan paling pesat di kabupaten Sumedang adalah Kecamatan Jatinangor yang direncanakan menjadi kawasan pendidikan. Kecamatan ini telah berkembang dengan peningkatan jumlah penduduk yang sangat cepat. Peningkatan tersebut berpengaruh pada meningkatnya kebutuhan air, dan dalam upaya memenuhi kebutuhan air masyarakat perkotaan tersebut dibentuklah PDAM oleh pemerintah Kabupaten Sumedang sebagai bentuk pelayanan dan pemenuhan kebutuhan air masyarakat diperkotaan seperti Jatinangor. Mogelgaard (2011) menyebutkan bahwa semakin banyaknya permintaan air bersih dari wilayah perkotaan juga telah meningkatkan stres pada sumber air tawar, yang mana stres tersebut dipicu oleh meningkatnya permintaan air yang sudah menyebabkan kelangkaan air. Terkait dengan stres air tawar itu, Falkenmark dan Widstrand (1992) menyebutkan bahwa suatu negara dinyatakan memiliki air yang langka jika terdapat kurang dari 1000 meter kubik air tawar terbarukan yang tersedia per orang pertahunnya, dan dinyatakan stres air jika tersedia air antara 1000 hingga 1667 meter kubik perorang pertahunnya.

Peningkatan jumlah hunian sebagai konsekuensi dari meningkatnya jumlah penduduk 
yang memicu munculnya penyedia layanan air bersih tersebut menjadi indikasi berubahnya makna air. Air yang karena perannya membentuk karakter identitas sosial-budaya masyarakat awalnya merupakan matriks budaya, dasar kehidupan (Godina 2005; Shiva 2002). Saat ini air telah berubah makna menjadi barang ekonomi (Briscoe, 1996) Meskipun beberapa peneliti menganggap air sebagai barang ekonomi tetapi peran air sebagai kebutuhan dasar,barang yang berharga, dan sebagai sumberdaya sosial, ekonomi, keuangan serta lingkungan, telah menyebabkan sumber daya ini tidak dapat dihapus dari perannya sebagai barang publik (Perry, Rock, dan Seckler 1997). Terkait air sebagai barang ekonomi (Briscoe 1996b), pendapat tersebut sejalan dengan empat prinsip Dublin, yaitu prinsip yang disepakati dalam konferensi air dan lingkungan yang diselenggarakan di Dublin (World Meteorological Organization 1992). Dalam empat prinsip tersebut pada poin keempat disebutkan bahwa air memiliki nilai ekonomi dan harus diakui sebagai barang ekonomi, dengan mempertimbangkan kriteria keterjangkauan dan kesetaraan (World Meteoro-logical Organization 1992). Di Indonesia, salah satu sumber air berciri sebagai barang ekonomi dan barang publik salah satunya adalah sumber air dari kawasan hutan Perhutani, karena distribusi dan alokasi yang dilakukan PDAM telah mengembangkan mekanisme ekonomi dalam memenuhi kebutuhan masyarakat akan air bersih. Sedangkan ciri publik dapat dilihat pada konteks pemanfaatan sumber air oleh masyarakat desa di tepian hutan.

Penggunaan sumber air bersama antara masyarakat desa dan perusahaan air minum yang menggunakan sistem perpipaan teknis dan barang ekonomi dengan menetapkan harga untuk setiap distribusi dan alokasi bagi masyarakat pengguna airtelah membentuk interaksi saling ketergantungan yang unik terutama pada sumber air dari hutan Perhutani ini, keunikan tersebut terlihat pada model pemanfaatan sumber air dimana masyarakat desa dapat memanfaatkan air secara bebas tanpa dikenakan beban biaya oleh Perhutani, sedangkan PDAM yang memanfaatkan air dari hutan Perhutani tersebut harus membayar untuk setiap meter kubik yang di distribusikannya. Saat ini interaksi saling ketergantungan pada air dari hutan Perhutani antara masyarakat desa dan PDAM mengalami gesekan karena peningkatan jumlah pelanggan PDAM yang mempengaruhi lonjakan kebutuhan air yang dialokasikan untuk PDAM.

Artikel ini berbasis penelitian perubahan sosial yang terjadi pada masyarakat pedesaan yang menggunakan air dari kawasan hutan Perhutani, dilihat dari basis, struktur, dan suprastruktur yang telah berubah karena adanya penggunaan sumber air secara bersama dengan PDAM yang jumlah pelanggannya terus bertambah.Melihat perubahan yang terjadi pada masyarakat desa yang juga memanfaatkan air dari sumber air yang sama akan memberikan perspektif baru bahwa penambahan populasi tidak hanya meningkatkan polusi dan kelangkaan air, tetapi juga akan berdampak pada terjadinya perubahan pada masyarakat desa yang memanfaatkan air dengan pola dan model penggunaan yang berbeda dari masyarakat diwilayah perkotaan.

Pendekatan yang dipergunakan dalam penelitian ini adalah pendekatan kualitatif dengan 
metode studi kasus instrumental (Denzin dan Lincoln 2009). Pemilihan studi kasus instrumental karena kasus pemanfaatan air dari hutan Perhutani secara bersama dengan PDAM ini dapat menjadi informasi pendukung yang memudahkan pemahaman kita mengenai kasuskasus pemanfaatan air dari hutan Perhutani di lokasi-lokasi yang berbeda. Pemilihan metode studi kasus ini dapat memberikan gambaran tipikal bagi kasus-kasus pemanfaatan air bersama antara masyarakat dan institusi bisnis yang terjadi di daerah yang lain.Oleh karena itu model kualitatif studi kasus menjadi pilihan karena keberadaan tempat, kekhususan dan keunikan kasus (Fisher dan Cresswell 1998). Teknik pengumpulan data dalam penelitian ini dilakukan dengan cara observasi partisipatif dan wawancara mendalam. Objek observasi partisipatif pada penelitian ini adalah tempat atau latar dimana penelitian ini dilakukan menyangkut aktivitas-aktivitas interaksi berkaitan dengan pemanfaatan air, antara masyarakat dengan masyarakat, masyarakat dengan Perhutani dan masyarakat dengan PDAM. Adapun wawancara dimaksudkan untuk mengumpulkan data secara akurat, sedangkan beberapa aspek yang menjadi fokus dalam wawancara yaitu mengenai perubahan infrastruktur (mode produksi dan mode reproduksi) akibat pemanfaatan bersama sumber air dengan PDAM, perubahan struktur sosial masyarakat sebagai akibat dari adanya pemanfaatan sumber air oleh PDAM, dan perubahan suprastruktur yang lebih melihat nilai dan cara pandang masyarakat desa tepian hutan terhadap kondisi lingkungan akibat berkurangnya pasokan air dari hutan Perhutani karena pemanfaatan bersama dengan PDAM.
Lebih lanjut mengenai penelitian terkait pemanfaatan air telah banyak dilakukan di Eropa, apakah itu yang berkorelasi dengan perubahan iklim atau privatisasi air (Alseaf 2017; Bakker 2005; Grey dan Sadoff 2006), sebuah artikel tentang distribusi air dan peraturan ditulis oleh (Grey dan Sadoff 2006) yang berpendapat bagaimana pertumbuhan cepat yang terjadi di suatu negara telah mendorong pengembangan infrastruktur sumber daya air tetapi perkembangan itu mengarah pada persepsi yang cukup umum bahwa pengembangan infrastruktur sumber daya air pada hakekatnya buruk bagi orang miskin, buruk bagi orang-orang yang terkena dampak proyek dan buruk bagi lingkungan. Namun, dari sejumlah penelitian, tidak ada yang menganalisis secara khusus perubahan apa yang telah dialami oleh masyarakat pedesaan yang sumber daya airnya digunakan oleh orang-orang di daerah lain, terutama di daerah perkotaan. Oleh karena itu, tema yang akan digaris bawahi untuk dibahas dalam kajian ini adalah: Perubahan Sosial Masyarakat Pemanfaat air dari hutan Perhutani; Perubahan Mode Produksi (infrastruktur); dan Pemanfaatan bersama sumber air dan perubahan struktur masyarakat desa;

Perubahan yang terjadi di masyarakat dianalisis menggunakan pendekatan teori materialisme historis dan materialisme budaya dengan melihat perubahan yang terjadi pada basis, infrastruktur, struktur, dan superstruktur di masyarakat pedesaan. Pada analisis menggunakan teori materialisme historis, Marx (Sztompka, 2007: 189), menyatakan bahwa ada tiga jenis faktor yang menyebabkan perubahan yang bekerja pada tiga tingkat berbeda, yaitu pada tingkat sejarah dunia, pada tingkat struktur, dan 
pada tingkat tindakan individu. Analisis dalam penelitian ini difokuskan pada struktur dan tingkat tindakan individu untuk melihat perubahan sosial yang terjadi dan dialami oleh masyarakat desa yang tinggal di tepian hutan. Pilihan untuk melihat pada tingkat struktur sosial ini karena pengaruh determinan jauh lebih lemah, dan akan dapat diamati kelas yang mengambil tindakan kolektif pada akhirnya dipandu oleh kepentingan ekonomi mereka dan bertujuan untuk memperkuat atau mempertahankannya. Analisis pada tingkat tindakan individu juga diperlukan untuk mengetahui apakah terdapat elemen sukarela yang paling kuat, pilihan bebas, keputusan spontan, kemungkinan, dan peluang dalam praktik pemanfaatan air dari hutan Perhutani ini di masyarakat.

Marx (dalam Sztompka 2007:189) mengemukakan bahwa proses perubahan dimulai pada tingkat tindakan individu. Tindakan individu ini yang merupakan kekuatan pendorong perubahan sosial dan historis. Individu adalah agen dari perubahan terakhir. Tetapi dalam tindakan mereka, individu harus menyadari kondisi struktural di sekitar mereka. Kesamaan kepentingan ekonomi menyatukan orang ke dalam kelas sosial dan pada saat yang sama membedakan mereka dengan anggota kelas sosial lainnya. Untuk mempertahankan kepentingan ekonomi mereka, kelas sosial memasuki perjuangan kelas dengan kelas yang berlawanan. Kelas progresif, yaitu mereka yang memiliki minat dalam mengembangkan "kekuatan produktif" akan lebih unggul. Mereka menciptakan sistem produksi baru. Kelas yang tersisa lainnya dipaksa untuk menyesuaikan diri dengan sistem ekonomi baru ini. Transformasi fundamentalis yang lengkap dari seluruh masyarakat, yaitu revolusi sosial. Maka kisah ini akan terulang kembali.

Selain itu, Marx juga menyediakan analisis perubahan sosial yang berbeda. Menurut Marx (dalam Munandar 1998:116) terjadinya akumulasi modal (modal) sebagai dasar untuk asumsi perubahan sosial. Marx memberikan posisi tertinggi pada realitas kondisi material dalam interaksi dialektik dengan realitas gagasan dan hubungan sosial. Proses perkembangan kapitalisme melahirkan perubahan sosial. Menurut Marx aktor utama perubahan sosial bukanlah individu tertentu, tetapi kelas sosial, oleh karena itu kita hanya dapat memahami sejarah dan perkembangan yang terjadi ketika kita memperhatikan kelas sosial dalam masyarakat. Marx menyebutkan bahwa setiap masyarakat terdapat kelas penguasa dan kelas yang dikontrol, kelas atas dan kelas bawah (dalam Suseno 2010).

Selanjutnya, Marx juga mengungkapkan bahwa masyarakat kapitalis terdiri dari tiga kelas, yaitu pekerja (mereka hidup dengan upah), pemilik modal (yang hidup dari laba), dan tuan tanah, dalam perkembangan selanjutnya ada dua kelas yang tersisa, pekerja dan pemilik modal. Marx (dalam Suseno, 2010) berbagi ruang lingkup kehidupan manusia dalam dua bagian utama, salah satunya adalah "basis nyata" atau "basis" dan yang lainnya adalah "bangunan atas". Basis nyata atau basis adalah bidang produksi kehidupan material, sedangkan bangunan atas adalah proses kehidupan sosial, politik dan spiritual. Kehidupan di atas ditentukan oleh kehidupan berdasarkan bangunan atas. Ini berarti bahwa perubahan sosial akan terjadi ketika perubahan terjadi atas dasar perubahan 
dalam produksi kehidupan material. Dasar atau basis ditentukan oleh dua faktor: kekuatan produktif (kekuatan yang digunakan oleh masyarakat untuk bekerja pada alam) dan hubungan produktif (hubungan kerja sama atau pembagian kerja antara manusia dalam proses produksi). Bangunan atas terdiri dari dua elemen; tatanan kelembagaan dan tatanan kesadaran kolektif juga disebut pembangunan ideologi (Suseno, 2010).

Jika teori Marx tersebut dikaitkan dengan pola dan mekanisme pemanfaatan sumber air dari hutan Perhutani, dapat dilihat bahwa perubahan ini terjadi karena struktur yang dikembangkan oleh PDAM adalah model penggunaan sumber air dengan teknologi, dan modal yang menyebabkan perubahan pola dan mata pencaharian pada masyarakat desa tepian hutan. Selanjutnya, pada analisis yang menggunakan teori materialisme budaya yang dikemukakan Marvin Harris tersebut berusaha melengkapi teori perubahan yang dikemukakan oleh Marx, khususnya dalam menganalisis perubahan dalam masyarakat. (Saifuddin 2006:236) menjelaskan bahwa Marvin Harris sangat dipengaruhi oleh ide-ide Marx tentang
Basis (Base) dan Superstruktur, yang mana oleh Marvin Harris dua hal tersebut disebut sebagai infrastruktur dasar. Selanjutnya untuk semakin memperkaya analisisnya, Marvin Harris memodifikasi skema yang dikemukakan Marx dengan memasukkan unsur-unsur reproduksi manusia ke dalam infrastruktur bersama dengan mode produksi ekonomi. Harris juga mengusulkan "kategori menengah", yaitu struktur, antara dasar dan superstruktur. Kategori ini tidak ditemukan dalam skema Marxis (Saifuddin 2006:236). Penggunaan analisis materialisme historis dari Marx yang mendasarkan perubahan sosial pada tiga tingkatan berbeda, yaitu sejarah dunia, tingkat struktur, dan tindakan individu, diyakini dapat memberikan pemahaman mengenai bagaimana perubahan sosial terjadi pada masyarakat pemanfaat air dari hutan Perhutani, sedangkan pada teori materialisme budaya, perubahan dilihat pada tingkat infrastruktur, struktur dan suprastruktur. Sehingga penggunaan kedua teori tersebut memberikan penjelasan yang berbeda terkait dengan perubahan sosial pada masyarakat desa pemanfaat air dari hutan Perhutani.

Tabel 1.

Perbedaan Basis/Infrastruktur Antara Marx dan Marvin Harris

\begin{tabular}{ll}
\hline \multicolumn{1}{c}{$\begin{array}{c}\text { Basis (Infrastruktur) } \\
\text { Karl Marx }\end{array}$} & \multicolumn{1}{c}{\begin{tabular}{c}
\multicolumn{1}{c}{ Basis (Infrastruktur) } \\
Marvin Harris
\end{tabular}} \\
\hline $\begin{array}{l}\text { Tenaga-Tenaga } \\
\text { Produktif } \\
\text { Hubungan-hubungan } \\
\text { Produksi }\end{array}$ & $\begin{array}{l}\text { Mode Produksi } \\
\text { Teknologi subsistensi, hubungan tekno-lingkungan, ekosistem, } \\
\text { pola-pola kerja }\end{array}$ \\
& $\begin{array}{l}\text { Mode Reproduksi } \\
\text { Teknologi dan praktik-praktik yang diterapkan untuk } \\
\text { memperluas, membatasi dan mempertahankan ukuran populasi } \\
\text { (demografi, pola-pola perkawinan, fertilitias, mortalitas) }\end{array}$ \\
&
\end{tabular}

Sumber: Suseno (2010) 


\section{Perubahan Sosial Masyarakat Pemanfaat air dari Hutan Perhutani}

Sebagai sumber air utama yang dimanfaatkan untuk berbagai keperluan masyarakat seperti tumah tangga hinggapertanian, sumber air dari hutan Perhutani memiliki peran yang sangat vital. Oleh karena itu, adanya pemanfaatan sumber air dari pihak lain di luar masyarakat desa, menyebabkan pasokan air bagi masyarakat desa mengalami gangguan. Gangguan akibat pemanfaatan sumber air yang sama oleh PDAM ini paling terlihat pada sektor pertanian. Meskipun tidak semua lahan pertanian sawah yang mengalami gangguan, akan tetapi setidaknya terdapat 30 hektar lahan sawah yang saat ini tidak lagi teraliri oleh air dari sumber air tersebut. Bagi masyarakat desa air yang berasal dari hutan Perhutani merupakan basis produksi material yang sejak awal dimanfaatkan untuk memenuhi kebutuhan subsisten masyarakat. Masyarakat memandang air sebagai sumberdaya untuk menghasilkan produksi pertanian sebagai upaya memenuhi kebutuhan mereka sendiri. Oleh karena itu, sebagai masyarakat yang mengandalkan pertanian padi sawah sebagai komoditi utamaterhambatnya pasokan air tersebut telah berdampak pada terjadinya perubahan pada masyarakat desa khususnya pada lahan-lahan yang tidak lagi teraliri oleh air dari sumber mata air tersebut. Perubahan paling nyata terlihat pada perubahan pola pertanian yang diterapkan oleh sebagian masyarakat. Jika sebelumnya seluruh masyarakat merupakan petani padi sawah, dengan adanya fenomena sebagian lahan yang tidak teraliri air tersebut jenis pertanian yang dibudidayakan mengalami perubahan. Beberapa komoditi yang dibudidayakan masyarakat di lahan yang tidak teraliri air tersebut diantaranya, hortikultura, dan palawija.

Perubahan pola tanam dan komoditi pertanian yang dibudidayakan oleh masyarakat petani itu juga berpengaruh pada berubahnya tingkat kebutuhan tenaga buruh tani. Pada pola pertanian padi sawah, sebelum berubah menjadi pertanian hortikultura kebutuhan buruh tani jauh lebih banyak, tenaga buruh tani dibutuhkan terutama pada awal tanam dan masa panen. Sedangkan pada pola pertanian hortikulutra kebutuhan buruh sangat jauh berkurang, hanya pada saat penyiapan lahan, sehingga sebagian buruh tani tersebut saat ini juga bekerja sebagai buruh tani di desa lain, dan sebagian yang lainnya tidak lagi bekerja sebagai buruh tani melainkan menjadi buruh bangunan, atau kuli angkut di pasar dan lain sebagainya. Ini menunjukkan bahwa berubahnya penguasaan sumber air telah berpengaruh banyak terutama pada masyarakat desa tepi hutan.

Melihat perubahan pola yang terjadi tersebut, maka dapat dilihat bahwa peralihan kontrol penguasaan pada sumber air dari sebelumnya sepenuhnya dimanfaatkan oleh masyarakat desa, dengan masuknya PDAM yang turut memanfaatkan sumber air yang sama untuk keperluan melayani masyarakat wilayah perkotaan sejauh ini telah merubah kontrol penguasaan sumber air menjadi berada di tangan PDAM. Meskipun kawasan hutan tempat sumber air berada di bawah penguasaan Perhutani, namun Perhutani tidak sepenuhnya mengatur alokasi dan distribusi sumber air tersebut, hal itulah yang membuat kontrol sumber daya air tersebut mengalami peralihan. Peralihan kontrol pada sumber air tersebut juga dipengaruhi oleh adanya kesepakat- 
an yang saling menguntungkan antara pihak Perhutani dan PDAM mengenai hak untuk memanfaatkan sumber air dari hutan Perhutani, sedangkan masyarakat dalam konteks Perhutani tidak memberikan keuntungan finansial karena masyarakat desa memanfaatkan air tersebut secara cuma-cuma.

Lebih jauh lagi, perubahan kontrol tersebut juga terjadi karena PDAM terus menambah jumlah pelanggan, sehingga alokasi air yang dialirkan untuk pelanggan PDAM menjadi lebih besar. Adapun dalam perkembangnya, untuk memberikan menjamin ketersediaan pasokan yang cukup bagi PDAM dan masyarakat, PDAM mendorong terbentuknya struktur pengelola air yang ada di tingkat desa yang disebut "ulu-Ulu". Yang mana tugas utama dari ulu-ulu ini adalah mengatur alokasi air sehingga dapat mencukupi kebutuhan semua pemanfaat air dari hutan Perhutani tersebut baik PDAM maupun masyarakat. Meskipun ulu-ulu mengatur alokasi air untuk masyarakat dan PDAM, namun dalam praktiknya ulu-ulu lebih berperan memastikan bahwa alokasi untuk PDAM tidak mengalami kendala.

Adanya struktur ulu-ulu yang dibentuk berdasarkan kesepakatan bersama antara PDAM dan masyarakat desa, menunjukkan bahwa dominasi penguasaan telah berada di PDAM, sehingga, masyarakat makin sedikit saja perannya dalam penguasaan air tersebut. Disisi lain, pada konteks Perhutani sebagai lembaga yang diberi hak dan kewenangan untuk mengelola hutan secara tegas mengatakan bahwa air dari mata air yang ada di wilayah hutan Perhutani dapat dimanfaatkan seluas-luasnya oleh masyarakat, sehingga mekanisme pengaturan alokasi dan distribusi murni hanya diselesaikan antara PDAM dan masyarakat desa pemanfaat air. Perhutani tidak menetapkan suatu syarat atau ketentuan yang secara explisit mengatur tentang pemanfaatan air dari hutan Perhutani, Perhutani hanya menetapkan syarat agar semua pemanfaat berperan dalam menjaga kondisi hutan agar tetap baik yang akan berpengaruh pada stabilitas jumlah air.

\section{Perubahan Mode Produksi (Infrastruktur)}

Perubahan pola pertanian yang terjadi karena dipengaruhi oleh berkurangnya pasokan air pada lahan pertanian masyarakat dimana sebelumnya jenis komoditi tanaman pertanian masyarakat didominasi oleh pertanian padi. Sebelum ada PDAM yang ikut memanfaatkan air dari mata air yang sama dengan masyarakat, masyarakat desa dapat bertanam padi sepanjang tahun, karena pasokan air yang mengalir terus menerus sepanjang tahun. Saat ini hampir semua lahan yang ada di wilayah desa ini diketahui hanya dapat menanam padi pada musim penghujan, hanya sebagian kecil saja yang masih dapat ditanami sepanjang tahun terutama yang aliran airnya tidak terganggu oleh PDAM. Saat ini diketahui bahwa pada musim kemarau khususnya, sebagian besar lahan sawah yang ada didesa ini tidak berproduksi. Perubahan pola pertanian yang hanya bertanam pada musim hujan ini berpengaruh pada tenaga-tenaga produktif dan hubungan hubungan produksi. Tenaga-tenaga produktif dalam hal ini di wakili oleh masyarakat yang bekerja sebagai buruh tani, hubunganhubungan produksi tersebut terganggu karena saat ini dengan berkurangnya pasokan air tersebut masyarakat yang bekerja sebagai buruh 
tani tersebut hanya bisa bekerja pada satu musim tanam saja, sedangkan setelah masa tanam tersebut berakhir masyarakat yang menjadi buruh tani tersebut harus bekerja yang ditempat lain untuk dapat melanjutkan hidupnya.

Selain itu, berkurangnya pasokan air, juga telah merubah pola pertanian dan sistem pertanian masyarakat. Perubahan sistem pertanian ini dapat dilihat pada masyarakat yang lahan sawahnya sama sekali tidak mendapatkan pasokan air. pada lahan pertanian seperti ini, yang dilakukan oleh masyarakat menanam komoditi lainnya selain padi sawah yaitu palawija, atau tembakau, itupun hanya mungkin dilakukan ketika musim hujan tiba, sehingga lahan pertanian mendapatkan cukup pasokan dari air hujan dan ketika musim kemarau tiba lahan sudah bisa dipanen. Perubahan pola dan sistem pertanian tersebut memperlihatkan bahwa berkurangnya air secara sosial telah berdampak berubahnya basis kehidupan masyarakat, berkurangnya pasokan air artinya berkurangnya pendapatan masyarakat petani.

Merujuk pada analisa materialisme historis yang dikemukakan oleh Marx perubahan yang terjadi pada masyarakat disebabkan oleh dikendalikannya alat produksi material yang dalam hal ini alat produksi material tersebut adalah air, air yang selama ini dikuasai sepenuhnya dalam kontrol masyarakat, ketika PDAM turut memanfaatkan sumber air yang sama tersebut, telah mendorong beralihnya kontrol pada sumber air tersebut. Peet dan Hartwick (2009:95-96) mengemukakan bahwa dalam teori Marxis diketahui bahwa transformasi historis kedua terjadi ketika alat-alat produksi dikendalikan oleh penguasa. Konsekuensi dari pengendalian ter- sebut adalah terciptanya pembelahan sosial mendasar, suatu hubungan kelas, antara pemilik kekuatan produktif dan buruh yang melakukan pekerjaan. Dalam konteks pemanfaatan air dari hutan Perhutani oleh masyarakat, turut sertanya perusahaan air minum daerah kabupaten Sumedang memanfaatkan sumber air yang dimanfaatkan oleh masyarakat desa ini sesuai dengan pola pengendalian alat produksi oleh penguasa yang dalam konteks ini bukan alat produksi yang dikendalikan tetapi sumberdaya produksi masyarakat. hal tersebut sangat berpengaruh pada terjadinya pembelahan sosial di masyarakat, yang mana pembelahan tersebut terjadi karena kepentingan untuk memenuhi kebutuhan air mereka terganggu.

Berubahnya pola dan sistem pertanian tersebut lebih jauh juga berpengaruh pada perubahan dalam struktur masyarakat, terutama perubahan pada mata pencaharian masyarakat desa. perubahan pada mata pencaharian ini secara langsung dipengaruhi oleh perubahan pola dan sistem pertanian, yang mana perubahan pada pola dan sistem pertanian tersebut sangat berpengaruh pada pendapatan petani. Perubahan pola tanam dari yang bisa bertanam sepanjang tahun menjadi hanya satu kali dalam satu tahun secara signifikan berpengaruh pada pendapatan masyarakat petani, terganggunya pendapatan ini juga berpengaruh pada kemampuan masyarakat petani untuk mempekerjakan buruh tani. Sehingga hal ini berpengaruh pada ketersediaan pekerjaan bagi anggota masyarakat yang mengandalkan kehidupannya dengan menjadi buruh tani. Pada pola pertanian padi, masyarakat yang bekerja sebagai buruh tani tidak pernah kehilangan pekerjaan di dalam desa. Berkembang- 
nya pola pertanian akibat pasokan air yang terganggu, banyak buruh tani yang kesulitan untuk mendapatkan pekerjaansebagai buruh tani karena beberapa komoditi pertanian yang dikembangkantidak memerlukan banyak tenaga kerja. Akibatnya, tidak tersedianya pekerjaan sebagai buruh tani di desamenyebabkan banyak buruh tani harus mencari pekerjaan lain di luar desa untuk memenuhi kebutuhan hidupnya terutama pada musim selain musim tanam. Beberapa jenis pekerjaan yang dipilih oleh buruh taniketika tidak menjadi buruh tani adalah menjadi kuli bangunan, tukang parkir, kuli angkut di pasar, dan lain-lain.

Persoalan pemanfaatan air yang dilakukan PDAM sebagai interpretasi dari struktur yang mapan memperlihatkan bahwa terjadinya perubahan pola pertanian pada masyarakat desa memperlihatkan bagaimana kelas sosial tertentu memainkan peran dalam mendorong perubahan pada masyarakat khususnya pada masyarakat kelas sosial dibawahnya. Perubahan yang terjadi pada masyarakat desa bukan disebabkan oleh individu sebagai pelakuknya, perubahan pola dan system pertanian masyarakat ini dilakukan oleh struktur dan kelas sosial tertentu. Marx (dalam Suseno, 2010) menyebutkan bahwa pelakupelaku utama perubahan sosial bukanlah kelompok atau individu tertentu, melaikan kelaskelas sosial. Dalam melihat perubahan pola dan system pertanian pada masyarakat, PDAM sebagai representasi dari kelas menengah dan kelas atas telah menjadi penyebab perubahan pada masyarakat desa. PDAM sebagai representasi kekuasaan, saat ini telah sepenuhnya mengontrol dan menguasai masyarakat desa, karena pola dan system pertanian masyarakat sangat bergantung pada pengaturan yang ditetapkan oleh PDAM kepada masyarakat melalui pengaturan yang dilakukan oleh ulu-ulu.

Secara keseluruhan, perubahan mode produksi ditandai dengan terjadinya perubahan kontrol pada sumber air sebagai implikasi dari bertambahnya pengguna jasa PDAM sehingga alokasi air yang diperuntukkan bagi PDAM menjadi lebih besar. Perubahan pada kontrol tersebut selanjutnya berpengaruh pada pola dan system pertanian masyarakat yang mana hal tersebut pada akhirnya berpengaruh pada terganggunya hubungan-hubungan produksi pertanian dan tenaga-tenaga produktif dalam pola pertanian padi sawah. Ketiga perubahan yang terjadi tersebut pada akhirnya berdampak pada perubahan struktur di dalam masyarakat desa. selanjutnya, perubahan juga terjadi pada pola pemanfaatan air rumah tangga, semakin berkurangnya pasokan air juga mendorong masyarakat menciptakan kesepakatan untuk mengatur mekanisme dan distribusi air yang dimanfaatkan untuk rumah tangga. Sejauh ini, karena air yang dimanfaatkan tidak dikenakan beban biaya, maka salah satu bentuk pengaturan yang dilakukan adalah dengan memungut iuran dari warga desa dimana iuran tersebut hanya dipergunakan untuk perawatan pada jaringan perpipaanyang mengalami kerusakan. Perubahan pada masyarakat desa ini memperlihatkan bahwa air sebagai basis produksi material masyarakat desa sangat penting, terjadinya kelangkaan air telah menyebabkan terjadinya perubahan pada mode produksi masyarakat, yaitu air yang langka menjadi pendorong perubahan pada berubahnya teknologi subsistensi, hubungan teknologi lingkungan, ekosisten dan pola kerja. 
Table 2.

Komposisi Pemanfaaat Air sebagai Pelanggan PDAM

\begin{tabular}{rlrrr}
\hline No & Kecamatan & $\begin{array}{r}\text { Jumlah } \\
\text { Populasi Kota }\end{array}$ & Jumlah Pelanggan & $\%$ \\
\hline 1 & Tanjungsari & 66.030 & 26.202 & $39,68 \%$ \\
2 & Pamulihan & 21.214 & 10.395 & $49,00 \%$ \\
3 & Jatinangor & 68.452 & 24.036 & $35,11 \%$ \\
4 & Cimanggung & 7.691 & 601 & $7,81 \%$ \\
5 & Sukasari & 33.506 & 0 & 0 \\
\hline
\end{tabular}

Sumber: Data PDAM Tirta Medal Kabupaten Sumedang, Tahun 2018

\section{Pemanfaatan Bersama Sumber Air dan Perubahan Struktur Masyarakat Desa}

Pada struktur masyarakat desa, perubahan terjadi sebagai implikasi dari berubahnya pola tanam pada masyarakat petani di desa. Perubahan pola tanam yang terjadi sebagai akibat dari berkurangnya pasokan air ini, berpengaruh sangat besar pada masyarakat, karena berdampak pada ekonomi keluarga, dan hubungan produksi yang selama ini terbangun antara petani pemilik lahan dengan buruh tani yang bekerja sebagai penggarap sawah. Pada konteks buruh tani, perubahan pola tanam tersebut juga berpengaruh secara langsung pada kehidupan mereka karena tidak adanya pekerjaan, juga karena tidak adanya sisa bagi hasil panen padi. Sebelum terjadi perubahan pola tanam padi tersebut, buruh tani bisa mendapatkan uang dan beras sebagai hasil dari bekerja di lahan sawah ketika musim panen tiba. Ketika pola pertanian berubah, hasil yang bisa diperoleh seorang buruh tani hanyalah uang, sedangkan beras harus dibeli dengan uang yang diperoleh tersebut. hal tersebut pada akhirnya, mendorong buruh tani untuk bekerja di tempat lain untuk memenuhi kebutuhan hidupnya.

Perubahan struktur yang dipengaruhi oleh perubahan pola dan sistem pertanian masyarakat tersebut, memperlihatkan bahwa ketika pola dan system pertanian berubah maka menjadi pendorong berubahnya komposisi masyarakat yang secara struktur memperlihatkan bahwa masingmasing individu buruh tani tersebut menjadi kelas sosial yang paling terdampak dari berubahnya pola dan system pertanian tersebut. Selanjutnya, kelangkaan air yang disebabkan adanya pemanfaatan sumber air oleh PDAM juga berpengaruh pada terbentuknya struktur pemanfaat air ditingkat RW, dimana struktur tersebut hanya bertanggung jawab mengatur alokasi dan distribusi air bagi warga masyarakat di RW. Adapula stuktur pengelola air (ulu-ulu) yang berperan mengatur distribusi dan alokasi air yang secara khusus mengatur kepentingan PDAM, dimana struktur tersebut memastikan bahwa alokasi yang diberikan kepada masyarakat cukup dan alokasi untuk PDAM tidak kurang.

Melihat perubahan yang telah terjadi pada masyarakat akibat adanya pemanfaatan sumber air bersama antara masyarakat dan PDAM ini, secara jangka panjang sangat memungkinkan bahwa perubahan yang terjadi tersebut berpotensi menjadi pemicu konflik antara masyarakat dengan PDAM. Jika PDAM tidak berupaya mencari sumber air lain untuk memenuhi kebutuhan pelanggannya yang terus bertambah, 
maka kehidupan ekonomi masyarakat yang tinggal di desa tepi hutan ini akan sangat terganggu. Pemanfaatan sumber air yang telah dilakukan selama ini saja telah mendorong perubahan cukup besar pada masyarakat desa yang mana perubahan tersebut dapat mendorong terjadinya proses pemiskinan pada masyarakat akibat tidak mendapatkan alokasi air yang cukup. Ditambah lagi trend perkembangan pemukiman di wilayah perkotaan juga semakin berkembang dimana perkembangan kota tersebut akan bermuara pada penambahan pelanggan bagi PDAM. Disisi lain, PDAM sebagai institusi penyedia layanan air bersih juga menarik bagi masyarakat perkotaan karena kepraktisan yang ditawarkan.

\section{Kesimpulan}

Berdasarkan pada uraian yang telah dikemukakan tersebut, beberapa hal yang dapat disimpulkan adalah sebagai berikut. Pertama, dimanfaatkannya sumber air masyarakat desa yang berada di kawasan hutan Perhutani oleh PDAM, telah menyebabkan terjadinya perubahan sosial pada masyarakat desa tepian hutan, perubahan tersebut terlihat dari berubahnya pola tanam dan komoditi pertanian masyarakat. Kedua, perubahan juga secara jelas terlihat pada perubahan mode produksi (infrastruktur) yang terlihat dari beralihnya kendali atas kontrol sumber air yang selama ini dalam kontrol masyarakat desa menjadi pada PDAM. Ketiga, beralihnya kendali atas sumber air yang selama ini dalam kendali masyarakat menjadi pada PDAM secara lebih jauh telah menyebabkan perubahan pada struktur masyarakat yang mana perubahan struktur tersebut sangat jelas terlihat dari berubahnya mata pencaharian masyarakat desa terutama pada masyarakat yang selama ini menjadi buruh tani. Selain itu, akibat beralihnya kendali atas sumber air pada PDAM juga telah menyebabkan perubahan struktur pada masyarakat desa yang mana hal tersebut diperlihatkan dengan dibentuknya struktur pemanfaat air yang ada ditingkat RW yang mana tugas utama struktur ini adalah mengatur alokasi dan distribusi air untuk kebutuhan rumah tangga. Keberadaan struktur ini memperlihatkan betapa kendali atas sumber air benar-benar telah beralih kepada PDAM.[]

\section{Daftar Pustaka}

Alseaf, Hassan F. 2017. "Water Privatization: Is Privatization of Water Utilities the Right approach to Achieve Efficient Water Resources Management?" Revista de Arquitetura IMED 6(1):3-13.

Bakker, Karen. 2005. "Neoliberalizing Nature? Market Environmentalism in Water Supply in England and Wales." Annals of the Association of American Geographers 95(3):542-65.

Briscoe, John. 1996a. Water as an Economic Good: Old and New Concepts and Implications for Analysis and Implementation. Colombo.

Briscoe, John. 1996b. "Water as an Economic Good: The Idea and What it Means in Practice." in a paper presented at the World Congress of the International Commission on Irrigation and Drainage. Cairo.

Briscoe, John. 2011. "Water as an Economic Good: Old and New Concepts and Implications for Analysis and Implementation." pp. 6165 in Treatise on Water Science. Vol. 1, ed. P. Wilderer. London: Elsevier. 
Denzin, Norman K. dan Yvonna S. Lincoln, ed. 2009. Handbook of Qualitatif Reseserch. Yogyakarta: Penerbit Pustaka Pelajar.

Falkenmark, M. dan C. Widstrand. 1992. Population Bulletin. Washington DC: Population Reference Bureau.

Fisher, Darrell dan John Cresswell. 1998. "Actual and Ideal Principal Interpersonal Behaviour." Learning Environments Research 1:231-47.

Glińska-Lewczuk, Katarzyna, Iwona Gołaś, Józef Koc, Anna Gotkowska-Płachta, Monika Harnisz, dan Andrzej Rochwerger. 2016. "The Impact of Urban Areas on the Water Quality Gradient along a Lowland River." Environmental Monitoring and Assessment 188(11):624.

Godina, Elena. 2005. "Water Wars: Privatization, Pollution, and Profit. By Vandana Shiva. Pp. 221. (Pluto Press, London, 2002.) £12.99, ISBN 0-745-318371, paperback." Journal of Biosocial Science 37(3):381-82.

Grey, David dan Claudia W. Sadoff. 2006. Water for Growth and Development: A Theme Document of the 4th World Water Forum. Mexico City: National Water Commission of Mexico.

Literathy, P. 1996. "Industrial Wastes and Water Pollution." h. 21-32 in Regional Approaches to Water Pollution in the Environment. NATO ASI Series (Series 2: Environment), ed. P. E. Rijtema dan V. Eliáš. Dordrecht: Springer.

Liyanage, Chamara P. dan Koichi Yamada. 2017. "Impact of Population Growth on the Water Quality of Natural Water Bodies." Sustainability 9(8):1405-18.

McGrane, Scott J. 2016. "Impacts of Urbanisation on Hydrological and Water Quality Dyna- mics, and Urban Water Management: A Review." Hydrological Sciences Journal 61(13):2295-2311.

Mogelgaard, Kathleen. 2011. Why Population Matters to Water Resources.

Morote-Seguido, Álvaro Francisco dan María Hernández-Hernández. 2016. “Green Areas and Water Management in Residential Developments in the European Western Mediterranean. A Case Study of Alicante, Spain." Geografisk Tidsskrift Danish Journal of Geography 116(2):190201.

Munandar, Soelaeman M. 1998. Dinamika Masyarakat Transisi: Mencari Alternatif Teori Sosiologi dan Arah Perubahan. Yogyakarta: Pustaka Pelajar.

Peet, Richard dan Elaine Rachel Hartwick. 2009. Theories of Development: Contentions, Arguments, Alternatives. London: Guilford Press.

Perry, C. J., M. Rock, dan D. Seckler. 1997. Water as an Economic Good: A Solution, or a Problem? Colombo: International Irrigation Management Institute.

Saifuddin, Achmad Fedyani. 2006. Antropologi Kontemporer: Pengantar Kritis untuk Paradigma. Jakarta: Kencana.

Shiva, Vandana. 2002. Water Wars: Privatization, Pollution, and Profit. London: Pluto Press.

Stoyanova, Zornitsa dan Hristina Harizanova. 2019. "Impact of Agriculture on Water Pollution." Agrofor 4(1):111-18.

Suseno, Suseno. 2010. "Analisis Faktor-faktor yang Mempengaruhi Tingkat Kemiskinan di Indonesia." Fenomena Ekonomi 1(1):3040. 
Sztompka, Piotr. 2007. Trust: A Sociological Theory. Cambridge: Cambridge University Press.

Turton, A. R. dan L. Ohlsson. 2018. Water Scarcity and Social Stability: Towards a Deeper Understanding of the Key Concepts Needed to Manage Water Scarcity in Developing Countries. Sweden.

Wijitkosum, Saowanee. 2012. Evaluation of Impacts of Spatial Land Use Changes on Soil Loss Using Remote Sensing and Gis in Huay Sai Royal Development Center. Thailand.
World Bank. 2018. Water Scarce Cities. Washington, DC: World Bank.

World Meteorological Organization. 1992. International Conference on Water and the Environment: Development Issues for the 21st Century, 26-31 January 1992, Dublin, Ireland: The Dublin Statement and Report of the Conference. Geneva, Switzerland: World Meteorological Organization. 